
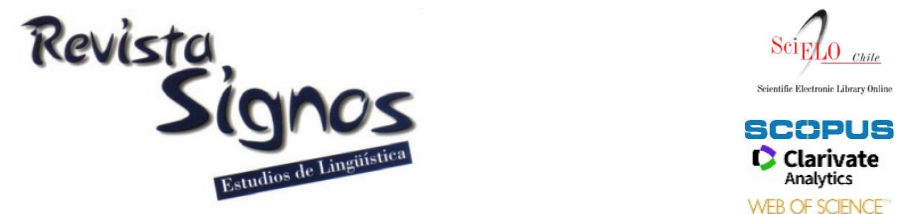

\title{
Transforming the community's linguistic landscape in a mixed-learner service learning capstone course in a Spanish for specific purposes program*
}

\section{Transformación del paisaje lingüistico de la comunidad en un trabajo fin de grado sobre el aprendizaje-servicio con aprendices mixtos en un programa de español con fines especificos}

\author{
Lourdes Sánchez-López \\ UNIVERSiTy of ALABAMA AT BirmingHAM \\ United STATES \\ lourdes@uab.edu
}

Recibido: 30-III-2018 / Aceptado: 15-X-2018
DOI: $10.4067 /$ S0718-09342019000300996

\begin{abstract}
This article explores an ecological approach to language teaching and learning and service-learning (van Lier, 1997; Tocaimaza-Hatch \& Walls, 2017) for the advanced mixed second language learner and heritage language learner classroom, in particular for Spanish for specific purposes in higher education in the United States (King de Ramírez, 2017). A new mixed learner capstone course for an Applied Professional Spanish major concentration focused on the transformation of the community's linguistic landscape (Landry \& Bourhis, 1997), uses community service learning linked to the professional interests of students (Sánchez-López, 2013a, 2013b; King de Ramírez, 2017; Abbott \& Martínez, 2018) to advance in their development of multiliteracy, intercultural competence, leadership skills, and social responsibility. To meet course goals, heritage and second language learners work as a team in close collaboration with community partners, to explore and transform the community's linguistic landscape in order to make public spaces more accessible, inclusive and welcoming to the Spanish-speaking community. The article offers a description of the pilot linguistic landscape project, which served as needs analysis to inform the development of the new capstone course, and its preliminary pedagogical implications.
\end{abstract}

Key Words: Spanish for specific purposes and the professions, community service learning, needs analysis, heritage language learning, team-based learning. 


\section{Resumen}

Este artículo explora un enfoque ecológico para la enseñanza y el aprendizaje de idiomas, y el aprendizaje-servicio (van Lier, 1997; Tocaimaza-Hatch \& Walls, 2017) para el aula avanzada mixta de aprendizaje de segunda lengua y el aprendizaje como lengua de herencia, en particular para español para fines específicos en la educación superior en los Estados Unidos (King de Ramírez, 2017). Un nuevo curso final mixto de una concentración de español profesional aplicado centrado en la transformación del paisaje lingüístico de la comunidad (Landry \& Bourhis, 1997) utiliza el aprendizaje en servicio comunitario vinculado a los intereses profesionales de los estudiantes (SánchezLópez, 2013a, 2013b; King de Ramírez, 2017; Abbott \& Martínez, 2018) para avanzar en su desarrollo de multialfabetismo, competencia intercultural, habilidades de liderazgo y responsabilidad social. Para cumplir con los objetivos del curso, aprendices de lengua de herencia y de segunda lengua trabajan en equipo en estrecha colaboración con los socios de la comunidad, para explorar y transformar el paisaje lingǘstico de la comunidad a fin de hacer que los espacios públicos sean más accesibles, inclusivos y acogedores para la comunidad de habla hispana. El artículo ofrece una descripción del proyecto piloto de paisaje lingüístico, que sirvió como análisis de necesidades para informar el desarrollo del nuevo curso final, y sus implicaciones pedagógicas preliminares.

Palabras Clave: Español con fines específicos y las profesiones, aprendizaje en servicio comunitario, análisis de necesidades, aprendizaje de lenguas de herencia, aprendizaje basado en equipos.

\section{INTRODUCTION}

This article explores the multimodal teaching and learning of advanced mixed second (L2) and heritage language (HL) learners in a Spanish for specific purposes program in higher education in the United States. A new advanced mixed learner (HL and L2) capstone course in an Applied Professional Spanish (APS) major uses community service learning (CSL) linked to the professional interests of the students (Lear, 2012, 2017; Sánchez-López, 2013a, 2013b; King de Ramírez, 2017; Abbott \& Martínez, 2018) to transform the community's linguistic landscape (Landry \& Bourhis, 1997) while helping learners advance in their development of multiliteracy, intercultural competence, leadership skills, and social responsibility. The overarching goal of this article is to explore Tocaimaza-Hatch and Walls' (2017) claim that service learning is an ecological (van Lier, 1997) resource for mixed second and heritage language classrooms, and thus, contribute to the current literature that supports this claim.

Since the 1970s Spanish heritage language (SHL) has been part of the educational system in the United States to accommodate the increasing number of Spanishspeaking students in the classroom (Valdés, 1991, 1997; Lynch, 2018). In the 1990s, SHL experienced significant progress as a result of abundant research and best practice development (Beaudrie, 2018). As the field advanced, in states and communities with higher numbers of heritage language learners (HLLs), HL and L2 
education became two separate tracks due to their distinctive linguistic goals, needs, and affective factors (Valdés, Fishman, Chávez \& Pérez, 2006; Beaudrie, Ducar \& Potowski, 2014), with SHL programs gradually expanding throughout the country. However, it is reported that less than half of colleges and universities in 26 states in the US with at least 5\% Hispanic enrollment offer separate tracks for Spanish HLLs and L2 learners (Beaudrie, 2012), and even when there exist separate tracks for the introductory and intermediate levels, the two tracks merge into one at the advancedlevel courses (Burgo, 2017; Carreira, 2017). These mixed classes are challenging for many teachers, as they lack the instructional training to manage both groups in one place simultaneously (García \& Blanco, 2000; Wilkinson, 2010; Carreira, 2012, 2017).

Moreover, given the rapid growth of the Spanish-speaking population in the US, along with an increasing interest in acquiring more advanced Spanish language proficiency, it is expected that the enrollment of Hispanic students in Spanish courses in higher education will continue to increase (Fairclough, 2015). As for instructional pedagogy and curricula in the US, the normative pedagogies used in the earlier years of the SHL movement was replaced in 1980s by a comprehensive approach based on critical pedagogy that raises HLLs awareness of the relationship between language and power within a community and that offers them some agency in their own learning (Carreira, 2012; Fairclough, 2015). Some scholars defend that in order to maximize HLLs learning outcomes in the college mixed Spanish classroom, we should seek ways to provide opportunities for empowering students by engaging them in active and independent learning, allowing them to build on their past experience (Burgo, 2017; Carreira, 2017).

As already stated, even when there exist separate tracks for HLLs and L2 learners in college Spanish programs, all learners merge in the same advanced classes as the two tracks disappear (Burgo, 2017; Carreira, 2012, 2017). This is true for all areas of study offered in the undergraduate major, such as literature, linguistics, culture, and more recently, Spanish for specific purposes (SSP) courses. The last decade has seen steady growth in the offering of SSP courses in the US higher education due largely to data suggesting a pressing need to revise foreign language curricula to better meet the needs of students and society (Modern Language Association, 2007). In that light, many university programs in the US are responding to these needs by adapting existing language programs or developing new ones (Doyle, 2010; Sánchez-López, 2010; Spaine Long, 2010, 2017; Long \& Uzcinski, 2012; Sánchez-López, Long \& Lafford, 2017; Brown \& Thompson, 2018). HHLs are particularly drawn to SSP courses (for example, Spanish for business, healthcare, translation, interpretation, law, law enforcement, etc.) due to their occupational intentionality. HLLs also find SSP courses useful as they typically lack knowledge of the technical terminology and specific language functions required in a specific profession, even though they may already be equipped with much of the cultural background included in the SSP 
curriculum (King de Ramírez, 2017; Tocaimaza-Hatch \& Walls, 2017; Abbott \& Martínez, 2018).

Central to such curricular revisions that have taken place in higher education to meet societal needs, community-based learning (CBL) and service learning (SL) have become fundamental in the higher education curriculum in the United States in the last decade (Long \& Uzcinski, 2012; Jorge, 2017). The integration of a Community Engagement category in the Classification of Institutions of Higher Education in the Carnegie Foundation in the Advancement of Teaching in 2006 led to the inclusion of community engagement credits in undergraduate requirements (Sánchez-López, 2014). One programmatic consequence is that the interweaving of community service learning (CSL) and languages for specific purposes (LSP) is increasing in practice (King de Ramírez \& Lafford, 2013; Sánchez-López, 2014; Abbott, 2017; King de Ramírez, 2017; Ruggiero, 2017; Salgado-Robles, in press; Sánchez-López et al., 2017). As CSL has steadily found a solid place in US higher education in the last two decades, it has recently been proposed that the integration of community service learning (CSL) in advanced SHL and mixed L2 courses is an 'ecological' and valuable resource (King de Ramírez, 2017; Tocaimaza-Hatch \& Walls, 2017). In addition, the SSP classroom is also seen an optimal place to help develop leadership skills that can be transferred to the professional world after graduation (Spaine Long, 2013; Uribe, LeLoup, Spaine Long \& Doyle, 2014; Sánchez-López, 2017; Wurr, 2017; Derby, LeLoup, Rasmussen \& Sales de Souza, 2017; Abbott \& Martínez, 2018).

The Department of Foreign Languages and Literatures in a midsized public university in the Southeast, has recently developed a new capstone course for its new APS major concentration, in which roughly one fourth of the students are HLLs. The 'Spanish for Leadership in the Professions' course provides a unique opportunity to practice APS through service learning by requiring a local practical experience. The course takes a team-based learning (TBL) approach ${ }^{1,2}$ (Michaelsen, Baumaan-Knight \& Fink, 2003; Sweet \& Michaelsen, 2012; Sibley \& Ostafichuck, 2014;) where Spanish heritage and second language learners work as a team in close collaboration with wellestablished community partners to explore and transform the community's linguistic landscape in order to make public spaces more accessible, inclusive and welcoming to the Spanish-speaking community. This article describes both the 'Spanish for Leadership in the Professions' capstone course, as well as the needs analysis process which informed the design of the course, offering some preliminary reflections based on its first pilot. 


\section{Background}

\subsection{Spanish for specific purposes, leadership, and heritage language learners}

Service learning is seen by some as an ecologically perfect didactic tool for HLLs within the context of Spanish for the professions (Lafford, 2009; Lear 2012, 2017; Fernández \& Osa-Melero, 2017; King de Ramírez, 2017; Tocaimaza-Hatch \& Walls, 2017; Abbott \& Martínez, 2018; Sánchez-López, 2019). LSP scholars argue that service learning, in an ecological way, provides adequate learning opportunities for heritage speakers to optimize their learning process and develop professional leadership skills within contexts and adaptable interactions. We would go a step further by claiming that the combination of SSP with service learning is the "perfect match' for HHLs by providing four reasons behind this claim. The first reason is that SSP courses and programs are aimed at adult students preferably with a general base of language proficiency, since this is necessary to be able to develop communicative skills in specific professional contexts (Sánchez-López, 2012). The second reason behind this argument is the empowerment that the HLL receives from Spanish for the professions to be able to analyze specialized discourse and, as a specialist, to take responsibility for the development of their own learning outside the classroom (Upton, 2012; Burgo, 2017; Carreira, 2017). The third reason is the development of leadership skills in the Spanish class for the professions, particularly in service learning, regardless of profession or rank (Spaine Long, 2013; Uribe et al., 2014; Derby et al., 2014; Doyle, 2017). The fourth reason is the need for intercultural communication. SSP learners need Spanish to communicate in specific professional contexts by using both the specific technical lexicon and by focusing on knowledge of the cultural context to promote clear and effective communicative exchange between professionals (Council of Europe, 2002; King de Ramírez \& Lafford, 2014). Both the CEFR (Council of Europe, 2002) and the World-Readiness Standards for Learning Languages (The National Standards Collaborative Board, 2015) reflect on the need to develop professional skills that allow the Spanish language learner to perform the tasks that are needed within a professional context. The development of their professional skills will depend on the success of linguistic communication and intercultural understanding. It is here, on the level of intercultural communication, precisely where the heritage speaker will have a clearer advantage over the L2 Spanish speaker and, for this reason, he/she will be able to feel more empowered within his/her own learning process as previously mentioned (King de Ramírez, 2017; Tocaimaza-Hatch \& Walls, 2017; Sánchez-López, 2019). For these reasons of empowerment, leadership, knowledge of the general language and intercultural communication capacity, we argue that SSP is the 'perfect match' for HLLs. 


\subsection{Linguistic landscape}

Linguistic landscape (LL) is an area of study defined as the "visibility and salience of languages on public and commercial signs in a given territory or region" (Landry \& Bourhis, 1997: 23). There are studies in sociolinguistics, sociology, social psychology, geography, and media studies related to LL. The languages used in public signs indicate what languages are or may become locally relevant (Kasanga, 2012). LL has become a useful tool to understand the evolution of urban space, and therefore the transformation of globalized societies of the $21^{\text {st }}$ century. Signage in public spaces describe the identity of cities. Some authors study the LL as it relates to power, and therefore as a way to construct collective identity. As societal identities evolve, the LL evolves too. As Gorter (2013: 191) states:

"The study of linguistic landscape aims to add another view to our knowledge about societal multilingualism by focusing on languages choices, hierarchy of languages, contact phenomena, regulation, and aspects of literacy".

As our societies become increasingly globalized, so do public spaces. But, the evolution of linguistic landscape (from monolingual to multilingual) does not occur at the same pace as societies become more linguistically diverse. In many cases, LLs can remain monolingual well after communities have become multilingual. Language policy has a direct implication on LL.

Even though English is the language widely spoken in the United States, the country does not have an official language recorded in the Constitution. In 2017, there were 57.5 million Hispanics in the United States, of which 41 million spoke primarily Spanish. It is predicted that this figure will escalate to 119 million in 2060 (United States Census Bureau, 2016). Alabama is no different than the rest of the country in that the Hispanic population has increased in the last two decades. It grew from $1.7 \%$ in 2000 to almost $4.2 \%$ in 2016, a nearly 145\% increase (United States Census Bureau, 2016). As the Hispanic community grows in the State and the number of Hispanic students increase at the university (from $1 \%$ at the turn of the $21^{\text {st }}$ century to almost $4.5 \%$ in 2017), the author became gradually interested in exploring the progress (or lack of it) of linguistic landscape in the largest city in the state of Alabama.

Although the author is unaware of an actual course anywhere else similar to 'Spanish for Leadership in the Professions', there exist some commonalities to courses recently described in publications by King de Ramírez (2017), Ruggiero (2017), and Tocaimaza-Hatch and Walls (2017). These scholars separately argue that service learning naturally provides an ecological and effective learning context for HLLs, which may be conducive to important personal growth. Even though TocaimazaHatch and Walls (2017) do not reference linguistic landscape in their work, their 
mixed second and heritage service learning class engaged in providing Spanish translations for a local zoo signage. They conclude that even though all students (L2 and HLL) experienced clear lexical gains, HLLs:

"were reported to have increased their awareness of their own status as bilinguals and to have acquired a deeper appreciation and validation for their own bilingualism and gratitude for the opportunity to give back to their own community" (Tocaimaza-Hatch \& Walls, 2017: 60).

Ruggiero (2017) reported on her CruCES Project, where again a mixed class of L2 and HLLs in the Memphis area sought to build capacity and foster community through micro projects in the community. The author found that HLLs:

"demonstrated a higher degree of cultural sensitivity at the outset of the project and experiences an increase in self confidence and self-esteem related to the purposeful application of their language skills" (Ruggiero, 2017: 45).

King de Ramírez (2017) also reported on a similar study conducted with a SL mixed class of L2 and HLLs in Arizona. She found that HLLs "learned to bridge gaps with Hispanic coworker and community members" (King de Ramírez, 2017: 67) rather quickly. Her findings also pointed out to an increased HLLs' awareness of immigration policy and how these affect families, perhaps their own, or families that they may know. King de Ramírez concluded that having HLLs participate in Spanish CSL "serve the linguistic and social needs of the HLs and may be an alternative to HL-specific language courses” (King de Ramírez, 2017: 68).

\section{Spanish for leadership in the professions: A capstone course for Spanish for specific purposes programs}

\subsection{Local and university background}

The University of Alabama at Birmingham (UAB) is a medium size (about 22,000 undergraduate and graduate students) public university in Birmingham, Alabama. It is also the largest employer in the state. Birmingham was a major center of activity of the Civil Rights Movement in the 1950s and 1960s, which lead to the passage of the Civil Rights Act in 1964. Today, Birmingham is a metropolitan city with a rapidly-growing Hispanic population over the last three decades as established above. Thus, hospitals, clinics, police and fire departments, government offices and local businesses have seen the increasing need to be able to communicate with Hispanic patients, customers and clients in Spanish. After a few years of a significant decrease in the growth of the Hispanic community due to an attempt to pass stricter anti-immigration laws (the Beason-Hammon Alabama Taxpayer and Citizen Protection Act, commonly known as H.B. 56) the Hispanic community is again on the rise in the State (United States Census Bureau, 2016). UAB was established in 1945 originally as the Medical Center 
of the university. The academic side of campus was later established in 1969, branching off from the University. Health-care and diversity are two of the best known and most marketed landmarks of the University.

UAB's Department of Foreign Languages and Literatures (DFLL) was established in the late 1960s as most languages departments were at the time, with a focus on language, literature and culture. The University had a language requirement for the core curriculum up to the late 1990s, when it was eliminated. The Department offers a major in Foreign Languages and Literatures with tracks in French and Spanish. In addition, it also offers minors in Chinese, French, German, Japanese, and Spanish, and introductory courses in Arabic, Italian, and Portuguese. A large percentage of students in the major are double majors in Spanish or French and another disciple (biology, chemistry, criminal justice, international studies, pre-medicine, pre-nursing along with Spanish are some of the most common double majors). With a long-term vision on the needs of the department and the community, at the turn of the $21^{\text {st }}$ century, the DFLL started offering courses in Spanish for healthcare, business, and translation and interpretation. The SSP courses were well received and offered on demand with regularity. As a consequence, two undergraduate programs were developed and established at the end of the 2000s: a Spanish for Specific Purposes Certificate, and a minor in Spanish for Business (to know more about the history and development of these programs, see Sánchez-López, 2013a).

Due to increasing student demand and to the natural evolution of the department, in 2018 the DFLL recently established a new major concentration in APS in their Bachelor of Arts in Foreign Languages and Literatures. This concentration is the most advanced option for Spanish majors who want to learn Spanish to use in professional contexts after graduation. This concentration culminates in an experiential, service learning capstone course, where students partner with community agencies and local professionals to transform the linguistic landscape.

\subsection{Needs analysis}

As stated, the new APS major concentration (2018) culminates in a required mixed learner capstone course titled 'Spanish for Leadership in the Professions'. This course was designed based on the results of a needs analysis process (Basturkmen, 2013; Brown, 2016; Sánchez-López, 2019) conducted in a previous advanced course offered by the author in 2016. In the 'Globalization in the Hispanic World' course learners studied major current globalization topics that affect the Spanish-speaking world, such as immigration trends and their consequences, Latinos in the US., and economic trade agreements. The instructor of the course (and author) decided to incorporate a semester-long, team-based learning project to serve as needs analysis for the aforementioned capstone. The project was titled 'Linguistic Landscape in Birmingham', and asked student teams to investigate where languages other than 
English were represented in public spaces. The instructor divided the city's public spaces into four major areas: (1) hospitals and clinics; (2) public transportation (airport, train and bus stations); (3) places of entertainment (movie theatres, malls, museums, institute of civil rights, zoo, botanical gardens, and parks); and (4) government buildings (city hall, public library, municipal court, legal department, and the citizen's assistance, the planning, engineering and permits, and the tax and license offices). The class was composed of 18 students, four HLLs and 14 L2 learners. The class was divided into four teams under a different topic each (healthcare, law and policy, services, and entertainment), and each HLL was asked to sign up for one of the teams. The rest of the students were asked to join one the teams (teams 1, 2, 3 and 4) according to their career interests. For the duration of the course, each team explored and mapped out their area of study, enthusiastically sharing their ongoing findings and snapshots in class each week. Each Thursday evening the once-a-week class became a lively centre of operations, where teams shared their findings with each other, and outlined an action plan for the following week. Towards the end of the course, Team 1 (healthcare), which had investigated signage in four major hospitals (a university hospital, a charity hospital, and two private hospitals) concluded that signage was bilingual in English and Spanish in some areas of the university and charity hospitals, in particular main lobbies, elevators and departments related to women's and pediatric health. Team 2 (public transportation) found signage to be mostly monolingual. Teams 3 (places of entertainment) found some bilingual signage in movie theatres and parks, but mostly monolingual signage in museums, institute of human rights, and zoo. Finally, Team 4 (government buildings) only found some bilingual signage in the municipal court. In the end, the class came to an eye-opening conclusion: despite the steadily growing diverse populations in Birmingham, a major centre of the Civil Rights Movement 50 years earlier, the language in public places remained rather monolingual. At the end of the semester, each team presented their project and results at UAB's Expo for Undergraduate Research, a major university-wide research-based conference open to undergraduate students from all disciplines. The four teams' poster presentations attracted a great deal of attention not only among the audience, but among the Expo judges as well. Team 1, whose team leader was a Cuban-American HLL, was awarded $1^{\text {st }}$ place in the Arts and Humanities category, and their project was featured with a full-length article in the Fall 2017 issue of the UAB Magazine (UAB Magazine, 2017).

\subsection{The capstone course: Spanish for Leadership in the Professions}

In 2016 the author was awarded a year-long institutional faculty fellowship in service learning and engaged scholarship to be completed during academic year 2016$2017^{3}$. As part of this program, the author designed the capstone course 'Spanish for Leadership in the Professions' for the new APS major concentration based largely on 
information gathered from the 'Linguistic Landscape in Birmingham' project described above, and the guidance of her program mentor. This culminating course was designed to provide an opportunity to practice APS through service learning by requiring a practical experience in the community. Using a team-based approach with a Spanish HLL per group, teams work side by side with well-established community partners to explore and transform the community's linguistic landscape in order to make public spaces more accessible, inclusive and welcoming to the Spanish-speaking community. The course was also designed following Sánchez-López’s (2013b) 18point guidelines for service learning course design for SSP programs. Under this model, faculty, community partners and leaners collaborate in a three-way partnership to establish learning outcomes and course assessment in order to optimize the linguistic and the intercultural learning outcomes of the students and, at the same time, the professional needs of the community. Although this model is not exclusive for HLLs, it has worked optimally with this population in the previous courses where it had been implemented at UAB.

The course offers six principal objectives:

(1) to spark, develop and nurture a varied spectrum of leadership skills;

(2) to serve as an agent of positive change of the community's linguistic landscape;

(3) to acquire a more profound understanding and appreciation of one's own community;

(4) to engage in meaningful service to one's own community;

(5) to advance the SSP proficiency development and cultural competency;

(6) to explore career paths.

The course content focuses on instructor lectures and invited guest lectures, where students discuss readings, films, and songs that explore the characteristics of Spanishspeaking communities and their experiences today in the United States. Through course materials students seek to understand what it means to be a Spanish-speaker in the United States today, how language affects identity, and the ways that individuals communicate and relate one another. A focal aspect of this course is service learning based on a team-based learning approach, where students join a team to work with a community partner according to their career interests for a minimum of three hours per week. Each team is composed of 2-3 Spanish L2Ls and one HLL. Teams engage in specific and intentional tasks to explore and transform the linguistic landscape of Birmingham in order to make public spaces more accessible, inclusive and welcoming to the Spanish-speaking community. Based on the results of the needs analysis, the most immediate LL projects incorporated in the new capstone include Spanish translations of signage at the Birmingham Museum of Art, the Zoo, The Birmingham 
Institute of Human Rights, The Civil Rights Trail, and the airport, train station and bus station.

\section{CONCLUSION}

The 'Spanish for Leadership in the Professions' course is the result of three interconnected lines of thought: the results of the needs analysis process described earlier, the careful reflection on almost two decades of teaching a previous mixedlearner advanced service learning language course, and the author's increasing interest in linguistic landscape as a field of study. All these factors led the author to the realization that her own students (both L2Ls and HLLs), if working in a team-based learning environment in collaboration with well-stablished community partners, could 'ecologically' become agents of positive change of their own community's public spaces. In this article we have also argued that the combination of SSP with service learning is the 'perfect match' for HHLs by providing four reasons behind this claim: empowerment, leadership, knowledge of the general language, and intercultural communication capacity. The 'Spanish for Leadership in the Professions' capstone from the Department of Foreign Languages and Literatures at UAB has been carefully designed to equally maximize the learning experience of both L2Ls and HLLs while making a long-term impact in the community's linguistic landscape, to enhance the L2Ls and HLLs' social responsibility awareness towards their own community and leadership skills, and to guide students in their life journey to become agents of positive change. Although this course has yet to be fully implemented, the author foresees a positive outcome based on the results yielded during the needs analysis and pilot stages. It is our intention to report on the full implementation of the course in the near future.

\section{REFERENCES}

Abbott, A. (2017). Civic engagement and community service learning: Connecting students' experiences to policy and advocacy. In M. Bloom \& C. Gascoigne (Eds.), Creating Experiential Learning Opportunities for Language Learners: Acting Locally while Thinking Globally (pp. 33-52). Bristol, UK: Multilingual Matters.

Abbott, A. \& Martínez, G. (2018). Spanish for the professions and community service learning: Applications with heritage learners. In K. Potowski (Ed.), The Routledge Handbook of Spanish as a Heritage Language (pp. 389-401). London, UK: Routledge.

Basturkmen, H. (2013). Needs analysis and syllabus design for language for specific purposes. In C. A. Chapelle (Ed.), The Encyclopedia of Applied Linguistics (pp. 4209-4217). Oxford, UK: Blackwell. 
Beaudrie, S. (2012). Research on university-based Spanish heritage language programs in the United States: The current state of affairs. In S. Beaudrie \& M. Fairclough (Eds.), Spanish as a Heritage Language in the United States: The State of the Field (pp. 203-221). Washington, DC: Georgetown University Press.

Beaudrie, S. (2018). Key issues in Spanish heritage language program design and administration. In K. Potowski (Ed.), The Routledge Handbook of Spanish as a Heritage Language (pp. 375-388). London, UK: Routledge.

Beaudrie, S., Ducar, C. \& Potowski, K. (2014). Heritage Language Teaching: Research and Practice. New York, NY: McGraw Hill.

Brown, A. V. \& Thompson, G. L. (2018). The Changing Landscape of Spanish Language Curricula: Designing Higher Education Programs for Diverse Students. Washington, DC: Georgetown University Press.

Brown, J. D. (2016). Introducing Needs Analysis and English for Specific Purposes. London, UK: Routledge.

Burgo, C. (2017). Meeting student needs: Integrating Spanish heritage language learners into the second language classroom. Hispania, 100(5), 45-50.

Carreira, M. (2012). Meeting the needs of heritage language learners: Approaches, strategies, and research. In S. M. Beaudrie \& M. Fairclough (Eds.), Spanish as a Heritage Language in the United States: The State of the Field (pp. 223-240). Washington, DC: Georgetown University Press.

Carreira, M. (2017). Learning for all: Addressing issues of access and participation in mixed classes. Hispania, 100(5), 51-52.

Council of Europe (2002). Marco Común Europeo de Referencia para las Lenguas: Aprendizaje, Enseñanza, Evaluación. Madrid, Spain: Anaya.

Derby, L., LeLoup, J., Rasmussen, J. \& Sales de Souza, I. (2017). Developing intercultural competence and leadership through LSP curricula. In M. Long (Ed.), Language for Specific Purposes: Trends in Curriculum Development (pp. 73-86). Washington, DC: Georgetown University Press.

Doyle, M. S. (2010). A responsive, integrative Spanish curriculum at UNC Charlotte. Hispania, 93(1), 80-84.

Doyle, M. S. (2017). Spanish for the professions and specific purposes: Curricular mainstay. Hispania, 100(5), 95-101. 
Fairclough, M. (2015). Spanish as a heritage language. In M. Lacorte (Ed.), The Routledge Handbook of Hispanic Applied Linguistics (pp. 134-149). London, UK: Routledge.

Fernández, V. M. \& Osa-Melero, L. (2017). Community engagement pedagogy: A tool to empower heritage language and second language integration. Hispania, 100(5), 53-54.

García, O. \& Blanco, G. (2000). Spanish for native speakers: K-12 considerations. In American Association of Teachers of Spanish and Portuguese (Ed.), Spanish for Native Speakers: AATSP Professional Development Series Handbook for Teachers K-16 (pp. 85-89). Fort Worth, TX: Harcourt College.

Gorter, D. (2013). Linguistic landscapes in a multilingual world. Annual Review of Applied Linguistics, 33, 190-212.

Kasanga, L. A. (2012). Mapping the linguistic landscape of a commercial neighbourhood in Central Phnom Penh. Journal of Multilingual and Multicultural Development, 33(6), 553-567.

King de Ramírez, C. (2017). Preparing students for the workplace: Heritage learners' experiences in professional community internships. In M. Long (Ed.), Language for Specific Purposes: Trends in Curriculum Development (pp. 55-72). Washington, DC: Georgetown University Press.

King de Ramírez, C. \& Lafford, B. (2013). Spanish for the professions: Program design and assessment. In L. Sánchez-López (Ed.), Scholarship and Teaching on Languages for Specific Purposes (pp. 31-41). Birmingham, AL: UAB Digital Collections.

King de Ramírez, C. \& Lafford. B. (2014). Spanish for the professions: Cultivating cultural intelligence in LSP programs. Cuadernos de ALDEEU, 28, 57-81.

Jorge, E. (2017). Where's the community? Redux. Hispania, 100(5), 175-180.

Lafford, B. (2009). Towards an Ecological CALL: Update to Garrett (1991). Modern Language Journal, 93, 673-696.

Landry R. \& Bourhis, R. (1997). Linguistic landscape and ethnolinguistic vitality. An empirical study. Journal of Language and Social Psychology, 16(1), 23-49.

Lear, D. (2012). LSP curriculum creation and implementation in service to the US community. Modern Language Journal, 96(1), 158-172.

Lear, D. (2017). For twenty-first century success, embrace both tradition and innovation. Hispania, 100(5), 183-184. 
Long, M. K. \& Uscinski, I. (2012). Evolution of languages for specific purposes programs in the United States: 1990-2011. Modern Language Journal, 96(1), 173189.

Lynch, A. (2018). A historical view of US Latinidad and Spanish as a heritage language. In K. Potowski (Ed.), The Routledge Handbook of Spanish as a Heritage Language (pp. 17-35). London, UK: Routledge.

Michaelsen, L., Bauman-Knight, A. \& Fink, D. (2003). Team-Based Learning: A Transformative Use of Small Groups in College Teaching. Sterling, VA: Stylus Publishing.

Modern Language Association (2007). Foreign languages and higher education: New structures for a changed world: The report of the MLA ad hoc committee on foreign languages [on line]. Retrieved from: http://www.mla.org/flreport

Ruggiero, D. (2017). The CruCES project: A consideration of service learning and intercultural sensitivity among heritage learners. Revista de Lenguas para Fines Especificos, 32(1), 45-62.

Salgado-Robles, F. (Ed.). (in press). Service-learning and Spanish for specific purposes in U.S. higher education. Cuadernos de ALDEEU, 33.

Sánchez-López, L. (2010). El español para fines específicos: La proliferación de programas creados para satisfacer las necesidades del siglo XXI. Hispania, 93(1), 85-89.

Sánchez-López, L. (2012). Spanish for specific purposes. In C. Chapel (Ed.), Encyclopedia of Applied Linguistics (pp. 5319-5326). Oxford, UK: Blackwell.

Sánchez-López, L. (Ed.). (2013a). Scholarship and Teaching on Languages for Specific Purposes. Birmingham, AL: UAB Digital Collections.

Sánchez-López, L. (2013b). Service learning course design in languages for specific purposes programs. Hispania, 96(2), 383-396.

Sánchez-López, L. (2014). An analysis of the integration of service learning in undergraduate Spanish for specific purposes programs in higher education in the United States. Cuadernos de ALDEEU, 28, 155-170.

Sánchez-López, L. (2017). Hacia el asentamiento del español para las profesiones y propósitos específicos. Hispania, 100(5), 104-106.

Sánchez-López, L. (2019). Spanish for the professions. In J. Muñoz-Basols, E. Gironzetti \& M. Lacorte (Eds.), The Routledge Handbook of Spanish Language 
Teaching: Metodologias, Contextos y Recursos para la Enseñanza del Español L2 (pp. 519-532). London, UK: Routledge.

Sánchez-López, L., Long, M. \& Lafford, B. (2017). New directions in LSP research in US higher education. In M. Long (Ed.), Languages for Specific Purposes: Trends in Curriculum Development (pp. 13-36). Washington, DC: Georgetown University Press.

Sibley, J. \& Ostafichuk, P. (2014). Getting Started with Team-Based Learning. Sterling, VA: Stylus Publishing.

Spaine Long, S. (Ed.). (2010). Curricular changes for Spanish and Portuguese in a new era. Hispania, 93(1).

Spaine Long, S. (2013). The unexpected Spanish for specific purposes professor: A tale of two institutions. In L. Sánchez-López (Ed.), Scholarship and Teaching on Languages for Specific Purposes (pp. 88-98). Birmingham, AL: UAB Digital Collections.

Spaine Long, S. (Ed.). (2017). Visionary essays: The future of Spanish and Portuguese. Hispania, 100(5).

Sweet, M. \& Michaelsen, L. K. (Eds.). (2012). Team-Based Learning in the Social Sciences and the Humanities. Sterling, VA: Stylus Publishing.

Team-Based Learning Collaborative (2018). What is TBL? [on line]. Retrieved from: http://www.teambasedlearning.org/

The National Standards Collaborative Board (2015). World-Readiness Standards for Learning Languages (4th ed.). Alexandria, VA: Author.

Tocaimaza-Hatch, C. \& Walls, L. (2017). Service learning as an ecological resource: Providing learning opportunities for mixed second and heritage language classrooms. In M. Bloom \& C. Gascoigne (Eds.), Creating Experiential Learning Opportunities for Language Leaners: Acting Locally while Thinking Globally (pp. 5371). Bristol, UK: Multilingual Matters.

United States Census Bureau (2016). [on line]. Retrieved from: http://www.census.gov/

University of Alabama at Birmingham. [on line]. Retrieved from: http://uab.edu/home/

Upton, T. A. (2012). LSP at 50: Looking back, looking forward. Ibérica, 23, 9-28. 
Uribe, D., LeLoup, J., Spaine Long, S. \& Doyle, M. S. (2014). Spanish at the United States Air force academy: Developing leaders of character and LSP curricular model. Cuadernos de ALDEEU, 28, 189-226.

UAB Faculty Fellowship for Engaged Scholarship (2017). [on line]. Retrieved from: https://www.uab.edu/servicelearning/faculty-guide/faculty-fellows-inengaged-scholarship

UAB Magazine (2017). Lay of the Language [on line]. Retrieved from: https://www.uab.edu/uabmagazine/features/lay-of-the-language

UAB Quality Enhancement Plan (2017). [on line]. Retrieved from: https://www.uab.edu/accreditation/qep

Valdés, G. (1991). Pedagogical implications of teaching Spanish to the Spanishspeaking in the United States. In G. Valdés, A. Lozano \& R. García-Moya (Eds.), Teaching Spanish to the Hispanic Bilingual: Issues, Aims, and Methods (pp. 320). New York, NY: Teachers College Press.

Valdés, G. (1997). The teaching of Spanish to Spanish-Speaking students: Outstanding issues and unanswered questions. In M. C. Colombi \& F. Alarcón (Eds.), La Enseñanza del Español a Hispanohablantes: Praxis y Teoría. Boston, MA. Houghton Mifflin.

Valdés, G., Fishman, J. A., Chávez, R. \& Pérez, W. (2006). Developing Minority Language Resources: The Case of Spanish in California. Clevedon, UK: Multilingual Matters.

Van Lier, L. (1997). Approaches to Observation in Classroom Research: Observation from an Ecological Perspective. TESOL Quarterly, 31(4), 783-787.

Wilkinson, S. L. (2010). A Survey of Utah Spanish Teachers Regarding the Instruction of Heritage Language Students of Spanish. Unpublished master's thesis, Brigham Young University, Utah, USA [on line]. Retrieved from: https:// scholarsarchive.byu.edu/cgi/viewcontent.cgi?article $=3330 \&$ context $=$ etd

Wurr, A. (2017). Multilingual leaners and learners. In M. Bloom \& C. Gascoigne (Eds.), Creating Experiential Learning Opportunities for Language Leaners: Acting Locally while Thinking Globally (pp. 3-7). Bristol, UK: Multilingual Matters.

\section{NOTES}

1 Team-based learning: 'Team-based learning is an evidence based collaborative learning teaching strategy designed around units of instruction, known as 'modules,' that are taught in a 
three-step cycle: preparation, in-class readiness assurance testing, and application-focused exercise.' (Team-Based Learning Collaborative, 2018)

2 The University of Alabama at Birmingham's current Quality Enhancement Plan's (QEP) topic is 'Learning in a Team Environment'. The skills UAB students develop as a result of this QEP will allow them to enhance their learning while at UAB, to enhance their engagement throughout all academic activities, and to enhance their opportunities for success in the workforce upon graduation. (University of Alabama at Birmingham's Quality Enhancement Plan)

3 UAB's Faculty Fellowship for Engaged Scholarship [on line]. Retrieved from:

https://www.uab.edu/servicelearning/faculty-guide/faculty-fellows-in-engaged-scholarship

\section{*ACKNOWLEDGEMENTS}

I would like to sincerely thank my UAB students in the Globalization in the Hispanic World course, who mapped out Birmingham's linguistic landscape for a course project. Their work guided me in the design of the 'Spanish for Leadership in the Professions' course presented in this article. I would also like to thank UAB's Office of Service Learning for awarding me with a Faculty Fellowship, during which I was able to design the course. I am also grateful to the anonymous reviewers for their valuable feedback in earlier drafts of this article. 